\title{
The sexual life of women with breast cancer: Meanings attributed to the diagnosis and its impact on sexuality
}

\author{
A vida sexual da mulher com câncer de mama: \\ significados atribuídos ao diagnóstico e \\ suas repercussões na sexualidade
}

\author{
Vanessa Monteiro CESNIK \\ Elisabeth Meloni VIEIRA² \\ Alain GIAMI $^{3}$ \\ Ana Maria de ALMEIDA ${ }^{4}$ \\ Daniela Barsotti SANTOS ${ }^{4}$ \\ Manoel Antônio dos SANTOS
}

\begin{abstract}
Breast cancer is the main neoplasm which affects women. It brings emotional problems in addition to physical and social problems due to affecting a bodily symbol of femininity. The aim of this study was to investigate the sexual life of women with breast cancer in the first year after the surgical procedure, seeking the meanings they attributed to the diagnosis and its repercussions on sexuality. Ten women who participated in a rehabilitation program were interviewed. In addition to the face to face interview their medical record were analyzed. Two categories emerged from the thematic analysis highlighting the negative and the positive impacts of this disease on the sexual life. This variety of meanings encountered shows that there no single pattern of sexual life after breast cancer. The way each woman reacts to the disease makes the way she experiences her sexuality unique. It follows that issues of sexuality must be incorporated in interventions offered in the context of care for these women.
\end{abstract}

Uniterms: Breast neoplasms; Mastectomy; Sexuality.

1 Universidade de São Paulo, Faculdade de Filosofia, Ciências e Letras de Ribeirão Preto, Departamento de Psicologia. Av. Bandeirantes, 3900, Monte Alegre, 14040-901, Ribeirão Preto, SP, Brasil. Correspondência para/Correspondence to: V.M. CESNIK. E-mail: <vmcesnik@yahoo.com.br>.

2 Universidade de São Paulo, Faculdade de Medicina. Ribeirão Preto, SP, Brasil.

3 Institut National de la Santé et de la Recherche Médicale. Paris, France.

4 Universidade de São Paulo, Escola de Enfermagem. Ribeirão Preto, SP, Brasil.

Article based on the Scientific Initiation of V.M. CESNIK, intitled "A vida sexual da mulher após a mastectomia". Universidade de São Paulo, 2011. Support: Fundação de Amparo à Pesquisa do Estado de São Paulo (Process nº 2009/15163-7). 


\section{Resumo}

O câncer de mama é a principal neoplasia que acomete as mulheres. Por afetar um símbolo corpóreo da feminilidade, produz alterações emocionais, que se somam às físicas e sociais. Este estudo teve por objetivo investigar a vida sexual da mulher com câncer de mama no primeiro ano após o procedimento cirúrgico, buscando-se demarcar os significados atribuídos ao diagnóstico e suas repercussões na sexualidade. Foram entrevistadas dez mulheres que participavam de um serviço de reabilitação. Além da entrevista individual realizou-se análise de prontuários. Da análise temática emergiram duas categorias, evidenciando o impacto tanto negativo como positivo do câncer na vida sexual. Essa variedade de significados encontrados mostra que não existe um padrão único de vivência sexual após o câncer. A maneira como cada mulher ressignifica o adoecimento contribui para que vivencie singularmente sua sexualidade. Conclui-se que é preciso incorporar questões de sexualidade nas intervenções oferecidas no contexto do cuidado a essas mulheres.

Unitermos: Neoplasias mamárias; Mastectomia; Sexualidade.

Breast cancer is a disease in which the prevalence and incidence has increased over recent years. In Brazil, the estimates of the Instituto Nacional do Câncer (INCA, National Cancer Institute) for the year 2010 were 49,240 new cases of breast cancer, while the estimates for the year 2012 indicate the occurrence of approximately 52,680 new cases (Brasil, 2009; 2011). According to INCA, breast cancer is probably the type of cancer that most frightens women, both due to its high prevalence, as well as its psychological and physical effects (Brasil, 2009).

Maluf, Dias and Barra (2006) claim that breast cancer is an important public health problem in Brazil, because it is the main neoplasm affecting women. By causing important physical, social and psychoemotional changes, this disease is detrimental to the quality of life, and represents a tangible threat that calls into question the ability of the affected person to remain alive (Scorsolini-Comin, Santos \& Souza, 2009).

Studies indicate the occurrence of different emotional reactions in the various stages of the treatment, from diagnosis to relapse (Bloom, 2002; Gimenes, 1997; Peres \& Santos, 2007). It is noticed that even when good results are obtained with the treatment, the experience of cancer often has a profound impact on the lives of the women affected. Many of them start to fear the threat of a recurrence of the disease and have difficulty dealing with the sequelae left by the treatment (Peres \& Santos, 2009; Silva \& Santos, 2008). For Vieira, Lopes and Shimo (2007), breast cancer destabilizes the psychic organization of women by bringing insecurity to their existence regarding the maintenance of life, the possibility of recurrence and the uncertainty about the success of the treatment.
Review studies show that breast cancer also produces important alterations in the body image and self-image of the women, which could affect their experience of sexuality and marital satisfaction (Biffi \& Mamede, 2004; Peres \& Santos, 2009; Santos \& Vieira, 2011). Women undergoing surgery for breast cancer report dissatisfaction and non-acceptance of the resulting physical changes. These feelings often negatively affect their sexual satisfaction and marital relationships (Bukovic et al., 2004; Fatone, Moadel, Foley, Fleming \& Jandorf, 2007; Santos \& Vieira, 2011). Often, during the treatment the affected women become weakened and report that they need to make an extra effort to function normally again, since experiencing breast cancer and the devastating effects of the treatment produce various alterations in sexual (Saegrov \& Halding, 2004) and social functioning (Sales, Paiva, Scandiuzzi \& Anjos, 2001).

Studies thatassess the psychological repercussions of the different types of surgical procedure for the removal of the breast nodule regarding the sexuality of patients indicate that, depending on the extent of the intervention, the emotional impact can be different, affecting the perception of the body and the sexual life. In the study of Gorisek, P. Krajnc and I. Krajnc (2009), women who underwent mastectomy reported a greater decrease in libido and more pronounced difficulties in relation to their interest in sex and to achieving orgasm than those who had conservative surgery. The results showed that the frequency of sexual activity was higher in women who had undergone breast-conserving surgery than in those who had undergone mastectomy. In agreement with these findings, Alicikus et al. (2009) showed that there was a more pronounced decrease in 
sexual desire in patients who underwent mastectomy (80\%) compared to women who had conservative surgery (61\%).

Research findings reveal that, the shorter the surgery time, the more problems related to sexuality tend to be detected, which indicates the need for studies that investigate women with a short time between the diagnosis and/or surgery and the end of primary cancer breast treatment (Avis, Crawford \& Manuel, 2004). According to Talhaferro, Lemos and Oliveira (2007), even when there was a satisfying sexual life in the stage prior to the illness, emotional stress, pain, fatigue, significant changes in body image and low self-esteem can disrupt the sexual functioning of the couple.

Such changes in sexual practice are experienced both due to the physical changes caused by the cancer and its treatment (breast loss, vaginal dryness, pain, discomfort), as well as the social coping with the disease, considering the family impact (Ambrósio \& Santos, 2011), the cultural beliefs, and the meanings attributed by the women to the breast cancer (Silva \& Santos, 2008). Despite the advances in treatment over recent decades, cancer remains a stigmatized disease and clearly associated with death (Gomes, Panobianco, Ferreira, Kebbe \& Meirelles, 2003; Silva \& Santos, 2010).

According to Lobo, Santos, Dourado and Lucia (2006), each person develops a particular way of dealing with issues related to their health and their body. Thus, regardless of the medical diagnoses and the physical changes that every woman experiences, satisfaction with life and their sense of happiness depend on their individual beliefs. Muniz (2008) complements this line of argument by stating that, in addition to providing the meanings, the culture also affects the response that each individual articulates when faced with the diagnosis and treatment of cancer. Sociocultural factors, therefore, also influence how each person will cope with the disease.

In addition to the concepts and collective representations offered by the cultural context in which the person is immersed, individual beliefs create interpretations and meanings regarding the cancer and the situations associated with it. These meanings directly affect the coping process and the adaptation to the different phases of the development and treatment of the disease, as highlighted by Gimenes (1997). The attitudes and behaviors of women affected by breast cancer depend on the meaning they attribute to the disease (Peres \& Santos, 2007). For this reason it is important to emphasize the impact of the cancer diagnosis on the experience of sexuality in women who underwent mastectomies (Araújo \& Fernandes, 2008; Rossi \& Santos, 2003).

Studies (Barton-Burke \& Gustason, 2007; Silva \& Santos, 2008) indicate the need to further explore this issue, in order to design new forms of intervention so that the women affected by breast cancer receive integral care from the healthcare professionals. They particularly need to receive support in the management of stress and changes in their sexual lives, caused by the limitations imposed by the disease and its invasive treatments.

Sexuality, the subject of inquiry of this study, is a fundamental dimension of the human being, seen from a broader perspective, it manifests itself in all stages of the life cycle and has just one of its many facets in the genitality (Büchele, Oliveira \& Pereira, 2006). In this sense, the concept of sexuality adopted in the present study considers the psychological, social and cultural dimensions involved (Santos \& Vieira, 2008). This expanded concept is in line with the thinking of authors such as Barton-Burke and Gustason (2007), who claim that sexuality is a very broad construct that encompasses an integration of the physical, psychological, social and cultural dimensions of the individuals.

This view contrasts with that sustained by other areas of knowledge. In the field of biomedical knowledge, the term "sexuality" has been reduced to the concept of "sexual function" and, more recently, incorporated into the concept of "sexual health". According to this notion, sexual function is constituted independently from reproductive function, so that sex is seen as a natural phenomenon and the sexual response cycle as a universal mechanism that is psychophysiologicaly similar in men and women (Giami, 2002; 2007).

According to World Health Organization (1986), good quality sexual activity or sexual happiness is a basic condition in the promotion of human health. The absence of sexual pleasure can trigger problems such as depression, mood swings, insomnia, and other symptoms indicative of psychological distress. For Talhaferro et al. (2007), our culture prevents clear and 
open communication and dialogue with respect to sexuality and sexual problems, which causes this issue not to be addressed by the majority of people, including professionals of hospital institutions and other healthcare professionals in general.

As proposed by Brêtas, Ohara and Querino (2008), the higher education forming agencies must commit to the need to educate students on the topic of sexuality, and the hospital institutions must invest in training their professionals, so that the future generations experience fewer problems related to this issue in the context of health.

The knowledge regarding sexuality generated from the perceptions and beliefs of women affected by breast cancer can contribute to improve the training, awareness and instrumentalization of psychologists and other healthcare professionals with respect to the issue and thus promote more qualified and integrated care. Faced with this problem, the present study aimed to investigate the sexual lives of women with breast cancer in the first year after the surgical procedure, seeking to demarcate the meanings attributed to the diagnosis and its impact on the sexuality.

\section{Method}

This is a descriptive, cross-sectional study with a qualitative approach.

\section{Participants}

A total of 10 women with breast cancer, between 36 and 62 years of age, attending a mastectomy rehabilitation service, located in the city of Ribeirão Preto, state of São Paulo, participated in this study. The study included women who had undergone surgery for removal of the breast lump within the period of one year, who practiced sexual activity before the onset of the disease and who agreed to cooperate with the research by signing the Terms of Free Prior Informed Consent, in accordance with the Conselho Nacional de Saúde (CNS) Resolution no 196/96 of the Ministério da Saúde (Ministry of Health). Women who had been sexually inactive for a long period prior to breast cancer were excluded, as were those with cognitive or clinical complications that made it impossible to participate in the study, women who had undergone breast reconstruction ${ }^{5}$, and cases of impairment due to relapse or metastasis (spread to distant sites) of the primary tumor.

Table 1, produced from the data obtained in the interviews, shows the demographic profile of the women interviewed. This characterization was drawn from the following personal data: age, marital/relationship status, number of children, education level, profession/ occupation, and religion.

Table 2 presents the data regarding the clinical profile of the participants, according to the type of

Table 1

Sociodemographic characteristics of the participants. Ribeirão Preto (SP), 2010

\begin{tabular}{|c|c|c|c|c|c|c|}
\hline Participants & Age (years) & Marital status & Children & Schooling & Profession/Occupation & Religion \\
\hline Amanda & 59 & Married & 3 & Incomplete Elementary Education & Housewife & Catholic \\
\hline Bianca & 62 & Separated & 2 & Incomplete High School Education & Massage Therapist & Spiritualist \\
\hline Clara & 55 & Married & 5 & Complete High School Education & Housewife & Catholic \\
\hline Dulce & 46 & Married & 1 & Complete High School Education & Housewife & Catholic \\
\hline Elisa & 52 & $\begin{array}{l}\text { Married for the } \\
\text { second time }\end{array}$ & 2 & Complete High School Education & Saleswoman & Catholic \\
\hline Fabiana & 37 & Married & 2 & Complete Elementary Education & Maid & Catholic \\
\hline Giovana & 36 & Married & 3 & Complete Elementary Education & Housewife & Catholic \\
\hline Heloisa & 57 & Married & 3 & Incomplete Elementary Education & Self-employed saleswoman & Catholic \\
\hline Irene & 59 & $\begin{array}{l}\text { Married for the } \\
\text { second time }\end{array}$ & 2 & Incomplete Elementary Education & Administrative Assistant & Catholic \\
\hline Janaina & 43 & $\begin{array}{l}\text { Married and with } \\
\text { boyfriend }\end{array}$ & 2 & Complete Higher Education & Teacher (kindergarten) & Evangelist \\
\hline
\end{tabular}

$\mathbf{s}$ It is considered that the implantation of breast prosthesis during or after the surgical removal of the lump can be a factor that influences the emotional issues raised regarding the perception of the body and sexuality of women. 
Table 2

Clinical profile of the study participants, according to the type of surgery, time since the diagnosis and since the surgery, and additional treatments performed: chemotherapy, radiotherapy and hormone therapy. Ribeirão Preto (SP), 2010

\begin{tabular}{llcclcc}
\hline Participants & Type of surgery & $\begin{array}{c}\text { Time since } \\
\text { diagnosis (months) }\end{array}$ & $\begin{array}{c}\text { Time since } \\
\text { surgery }\end{array}$ & $\begin{array}{c}\text { Chemotherapy) } \\
\text { (stage) }\end{array}$ & $\begin{array}{c}\text { Radiotherapy } \\
\text { (stage) }\end{array}$ & $\begin{array}{c}\text { Length of } \\
\text { hormone therapy } \\
\text { (months) }\end{array}$ \\
\hline Amanda & Simple mastectomy & 15 & 7 & Pre-surgery & Post-surgery & 6 \\
Bianca & Radical mastectomy & 17 & 7 & Pre-surgery & Post-surgery & 9 \\
Clara & Lumpectomy & 2 & 2 & Not performed & Post-surgery & 1 \\
Dulce & Lumpectomy & 13 & 5 & Pre-surgery & Not performed & 4 \\
Elisa & Simple mastectomy & 15 & 7 & Pre-and post-surgery & Post-surgery & Not performed \\
Fabiana & Lumpectomy & 8 & 8 & Post-surgery & Post-surgery & 11 \\
Giovana & Lumpectomy & 15 & 6 & Pre-surgery & Post-surgery & 11 \\
Heloise & Lumpectomy & 9 & 9 & Post-surgery & Post-surgery & Not performed \\
Irene & Lumpectomy & 9 & 9 & Pre-surgery & Post-surgery & 1 \\
Janaina & Lumpectomy & 11 & 10 & Post-surgery & Post-surgery & Not performed \\
\hline
\end{tabular}

Note: "lumpectomy: conserving surgery, when a small part of the breast affected by the cancerous nodule is removed; Simple mastectomy: when the entire breast is removed, without compromising the pectoral muscle; radical mastectomy: when, in addition to the total removal of the breast, the chest muscles are removed (Barros et al., 2001).

${ }^{* *}$ The time was calculated taking the date of the interview as the final parameter.

surgical procedure, time of the diagnosis and surgery, and additional treatments: chemotherapy, radiotherapy and hormone therapy.

\section{Instruments}

The following data collection instruments were used: individual interviews and documental analysis. The documental analysis was performed using a form for the clinical data obtained from the individual medical records of the participants, through the consultation of the rehabilitation service files.

The semistructured interviews were guided by a script, especially designed to meet the objectives of this study. The questions were formulated from a consultation of the literature of the area and from the experience of the researchers in psychosocial care to women with mastectomies. The semi-structured interviews covered information concerning the sexual life: number of sexual partners, frequency of sexual intercourse, sexual interest and satisfaction, attractiveness, the perception of her own body after surgery for breast cancer, how she thinks others viewed her before and after the disease, and sources of satisfaction and dissatisfaction with her own body and in the relationship with an intimate partner.

The interviews were administered individually, in a face to face situation, in a private room of the rehabilitation service which the participants were attending, ensuring comfortable and private conditions. To ensure greater reliability and objectivity in the recording of the reports, the interviews were audio recorded with the consent of the participants.

The interruption of the data collection occurred through theoretical saturation, which is operationally defined as a "Suspension of adding new participants when the data obtained begin to present, from the assessment of the researcher, a certain redundancy or repetition, with it not being considered relevant to persist in the data collection" (Fontarella, Ricas \& Turato, 2008, p.17). Thus, the criterion for the suspension of data collection was considered when it was found that the information provided by the study participants stopped adding new information to the material already obtained, in a way that it no longer substantially contributed to the improvement of the theoretical reflection based on the data collected.

In compliance with the criterion of data saturation, each interview was transcribed shortly after its completion, in order to be able to identify the emergence of possible recurrences and repetitions in the responses obtained. The research corpus was composed of the audio-recorded records, transcribed verbatim and literally. The data were subjected to thematic content analysis (Triviños, 1987), from which the units of meaning were highlighted, which in turn 
generated the categories. The data were interpreted with the support of the scientific literature.

The research project was approved by the Research Ethics Committee of the Escola de Enfermagem de Ribeirão Preto (Protocol no 1082/2009). Each participant was required to sign the Terms of Free Prior Informed Consent. Ethical care constitutes a delicate part of research, particularly regarding vulnerable populations, such as cancer patients, considering the bioethical issues raised by the theme of cancer (Kovács, 2003).

Respect for the autonomy of the participants was adopted as a guiding principle, according to the standards set by the National Health Council, in Resolution no 196/96 regarding research with humans. The users of the service were fully informed about the aims and procedures of the study, as well as about the foreseeable risks arising from their participation in the study. They were informed of the possibility of ceasing their participation, at any time, without incurring any form of prejudice to the monitoring performed in the service. They were also assured of the confidentiality that protects the information provided, as well as the preservation of their anonymity.

\section{Results and Discussion}

The results are presented and discussed according to the thematic categories (and their respective subcategories) that emerged from the analysis. The present study constitutes a design that includes two analytical categories: "negative impact of the breast cancer diagnosis on the sexual life" and "positive impact of the breast cancer diagnosis on the sexual life". According to the reports obtained, the diagnosis is experienced as both a negative and positive affect on the sexual life of the women affected. The participants have been given fictitious names in order to protect their identities.

\section{Negative impact of the breast cancer diagnosis on the sexual life}

Concern with the proximity of death: The concern 192 with the proximity of death was an experience that exerted a negative influence on the experience of sexuality, as can be seen in the statement of Heloisa:

P (Participant): I think, forme, it caused a change. Because of the problems....You're like this, wanting to cry, you know? I (Interviewer): What factors do you think... disrupted you more?

P: I think it also depends, it could be my mind, it could be myself, you know? I think I get very focused on that, you know, on... thinking about the problem... because you see: "Oh, breast cancer. oh, a cancer!". You are like this. When I found out, wow, I was really desperate, you know? Very much so. I thought it was the end of the world, you know? I could not imagine it was like this, that I didn't... I will not diefrom this. But you become worried, you know (Heloisa, 57 years, married, lumpectomy).

Trincaus and Côrrea (2006) report that the theme of death frequently permeates the statements of cancer patients. According to Kovács (1992), fear is the most common psychological response faced with death. Studies indicate that fear of death is a feeling commonly experienced by patients with breast cancer and deserves special attention from the healthcare professionals (Berterö \&Wilmoth, 2007; Corbellini, 2001).

In the present study it was perceived that the moment of the diagnosis raises worry and fear in the women affected by breast cancer regarding the possibility of experiencing their own finitude, corroborating findings of previous studies (Peres \& Santos, 2007, 2009; Rossi \& Santos, 2003; Silva \& Santos, 2008; 2010). The uncomfortable feelings may hinder the elaboration of the adverse experiences and the enjoyment of a fuller and more satisfactorily sexual life.

Fear of bodily alterations caused by the treatments: The diagnosis of breast cancer brings with it fantasies and fears regarding bodily alterations caused by the treatments, suggesting an anticipatory anxiety, as can be illustrated by the statement of Bianca:

It was as soon as I discovered that I had breast cancer, I immediately found a way to end my relationship... . lended this relationship because I said: I'll lose my hair... I will lose the breast... (Bianca, 62, separated, radical mastectomy).

Upon learning of the diagnosis of breast cancer, this participant developed a belief in relation to the potentially devastating consequences that the treatment could have on her physical appearance, due 
to its adverse effects, such as alopecia and mutilation, leading to bodily disfigurement. This anticipation had a negative impact on her relationship, dramatically marking her affective-sexual life. The emotional response to the possibility of harmful effects, even before they solidify, indicates that the physical repercussions of the breast cancer and its treatments are known and envisaged even before they occur. This predictability of the physical discomfort and bodily mutilation, which is perceived from the confirmation of the breast cancer diagnosis, may be, according to the Ministry of Health (Brasil, 2009), one of the major causes of the fear found in the female population in relation to this type of cancer. Such fear can directly influence the seeking of medical care, increasing rates of late diagnosis, which limits the chances of achieving successful treatment.

\section{Sexual intercourse as a risk for developing a new cancer}

This thematic category was drawn from the statements that linked sexual relations with the risk of a new cancer - that is, the belief in the possibility of the mammary tumor spreading to other parts of the body related to the female sexual apparatus -, or even the belief in the possibility of transmitting the cancer to the sexual partner - the concept of cancer as a contagious and sexually transmitted disease. This line of thinking can be perceived in the following excerpt from the interview, in which Elisa reports beginning to dread intercourse after breast cancer for fear that the disease would spread to other parts of the body, especially the uterus and ovaries:

I think that, maybe, it can give me problems in the uterus, in the ovary, you know? Me? I want to avoid this, I want to avoid this....if my cancer goes to the uterus, to the ovary, I'm afraid of that....and I think this [sex] is going to harm me. ...so sometimes I don't want it. I avoid it, I say no... (Elisa, 52 years, married for the second time, simple mastectomy).

The extract below indicates the perception of the cancer as a Sexually Transmitted Disease (STD).

And I thought it was going to pass to him too. ...because they always say it's in the blood, don't they? ... and ...they say, right, that it would be transmitted if he was having sex with me, l'd pass it to him... (Giovana, 36 years, married, lumpectomy).

The historical discussion produced by Sant'Anna (2000) about the relationship between cancer and the woman illuminates important aspects of the meanings popularly associated with the disease over the centuries. According to the study, from the nineteenth century to the early twentieth century, cancer was considered a contagious disease and associated with poor physical and moral hygiene and cleanliness. Similarly, it was considered that the disease could be contracted from the abuse of pleasures, especially in the case women, whose illness was seen as the result of their excesses, sins and nefarious vices, mainly related to the exercise of sexuality.

In the national context, several studies have investigated the beliefs and metaphors produced in coping with cancer (Lôbo et al., 2006; Tavares \& Trad, 2005). These thoughts will change over time and vary according to the sociocultural context in which they are immersed, however, part of them remains rooted in the Brazilian culture, therefore, it is very important to understand how these beliefs and taboos were constituted and crystallized (or modified) throughout history.

Other studies have reported the emergence of the discourse of cancer as a contagious disease. This perception is reflected in both the accounts of the affected people as well as in the reports of relatives and friends, who started to avoid contact with the affected individuals and with the objects they had touched. These findings confirm that cancer remains fixed in the popular imagination as a contagious disease that often produces reactions of embarrassment and awkwardness, which help to perpetuate the stigma that exists around the disease and the patient (Peres \& Santos, 2007; Silva, 2005; Silva \& Santos, 2010).

\section{Positive impact of the breast cancer diagnosis on the sexual life}

Surprisingly, a positive impact of the illness on the sexual life of women was also detected in this study. For some participants, the changes caused by the disease were positive, as it made them value their lives even more and potentialized new ways of expressing their sexuality, as can be seen in the following subcategories: 
- The proximity of death as a factor in promoting the valorization of life: The proximity to finitude was considered by some participants as a divine warning, i.e., it acted as a warning for them to become aware of the need to reassess how they had led their life up to then, which contributed to them revising their values and reconsidering some priorities. In the following report it can be seen that the meaning the participant attributes to the cancer does not revoke the suffering of the patient inherent in the disease condition and the experience of illness, but provides encouragement and stress relief when highlighting this painful experience endowing it with a purifying meaning.

So, for me the cancer was a way of... god shook me to say:
"You need to take care ofyourself... I mean, I passed... close
to death, so I have to live. So I think that, for me, undergoing
the suffering was something that I... I was uplifted... it's
something that hurt a lot, but for me it was a, how can I
say? One way that God saw fit to call me for life... I have
to live, I can live, it is not that... it is, that I must live for me,
for my daughter, for my husband....even in the suffering
it is... it was something that, that was good for me, right?
Us, the relationship improved, right? (Dulce, 46 years,
married, lumpectomy).

The perception of cancer as a transforming agent is present in the scientific literature, indicating that to experience the neoplastic disease can be related to the possibility of death and that this proximity to finitude can, paradoxically, be a potentiator for the revalorization of life (Araújo \& Fernandes, 2008; Kovács, 1992; KüblerRoss, 2005; Peres \& Santos, 2007; Silva \& Santos, 2008). It can be a transformative experience, in that it encourages women to reevaluate their lives, reviewing their feelings, values and priorities, which provides benefits for the affected person.

In the statement of Dulce it can be inferred that, with the experience of the disease, there seems to have been a positive resignification of her life, finding in the cancer a chance for growth, to view things differently and to develop a sense of self-respect, although under the influence of the suffering. This same interpretative vertex can be found in studies (Avis et al., 2004; Duarte \& Andrade, 2003) that show that, despite the problems experienced with the removal of the breast, some women reported that their sexual life had improved, as was mentioned in the discourse extract presented.
- The valorization of life as a facilitating factor for caring for the physical appearance: From the valorization of life mentioned, changes may also appear in relation to caring for the physical appearance, which was previously systematically neglected. With this, the woman can experience positive change in her sexual life, as can be glimpsed in the report of Janaina, reproduced below:

So, the time that they said cancer, the first thing that I thought... cancer, I'm going to die... . I had a new opportunity for life, so why don't I change my life? I want to change my life, I want it to happen differently... I think cancer for me was something like... how can I tell you... it's not that it was a good thing, but it made me become better than I was, understand?... it made me see the... is... I could see life differently..., because before I did not, I did not bother with my appearance, you know, for me any clothes were good, it was always going to work in T-shirts and shorts, you know? Not today, today I want to put on lipstick, which was something I didn't do, I want to carefor my appearance... . And, you know, I changed for the better... it was not for the worse, for me, for me it was for the better (Janaina, 43, married and with a boyfriend, lumpectomy).

This participant seems to have operated a redefinition of the cancer as a critical event that made her perceive life in a different way than previously. With this rotation of perspective, the participant started to care for herself more, giving importance to her physical appearance and her subjective well-being. In the wake of this process in which she could expand her perception, this participant found herself transformed into a better person than she was before the onset, which even drove to seek an extramarital relationship as a way to deal with the deep emotional and sexual dissatisfaction that she experienced maintaining a failed marriage. In this case, the failure of the marital relationship was prior to the advent of the disease.

\section{Final Considerations}

In this study there was a wide variety of experiences of sexuality that emerged or were potentiated after the breast cancer. This indicates that there is no single standard that can be deduced to describe the experience of sexuality of women facing the setbacks of breast cancer and the forcefulness of its 
treatments. It can be perceived that the way each participant dealt with the issue of the illness and treatment, as well as the meanings attributed to these vital events, made her singularly experience sexuality in relation to herself, her values and positions assumed faced with her own existence, or in the sphere of the relationship established with her sexual partner.

In this direction, it is important to point out that one of the limitations of this study is the lack of listening to the discourses of the intimate partners of the women interviewed, to include more elements related to the study. This view of the partners may be useful to complement the results obtained by this study, which focused on the issue exclusively from the point of view of the women. To ensure integral care for the women in relation to their sexuality it is interesting to help professionals perceive the partner as a possible factor of help in the recovery and psychosocial rehabilitation.

These considerations show the importance that, in future studies, the experiences of sexuality are taken into account when investigating the pattern of adaptation and psychosocial adjustment of women affected by breast cancer. An affective-satisfying sexual life can be one of the protective factors for the physical and emotional health of women facing breast cancer and the rigors of its invasive treatments. The findings of this study are relevant not only in the field of Psychology, but also in other areas of health, since they refer to an aspect of breast cancer that requires greater comprehension for the implementation of integral care strategies.

Considering the findings of this study, some implications of its results can be glimpsed for the psychologist in the health context. It was clear that, due to the different meanings attributed by the women to breast cancer, they experienced diverse problems and difficulties in relation to the sexual life after the diagnosis. In considering this question, the professional who works in the area of oncology psychology should aim for the psychological well-being of the patient, helping them to identify and comprehend the emotional factors involved in their health, allowing these to be redesigned. Furthermore, it is important to assist the patient to comprehend the meanings that the experience of illness have for her and to promote the development of reinterpretations of this process, which will help her to develop adaptive strategies to cope with the stressful situations in the prolonged itinerary of the treatment.

The more the patient is informed about her disease, treatments and prognosis, the greater her ability to cope with the illness, leading to more confidence being placed in the professionals of the multidisciplinary healthcare team. Thus, another relevant role that is worth the psychologist performing in the multidisciplinary team is to promote psychoeducational activities to keep patients informed and supported, in order to offer other possibilities of available discourses to increase resilience and strengthen the coping process.

Spending time in groups composed of people with similar problems provides an experience that can contribute to the development of an emotional climate of therapeutic value. This helps participants overcome barriers created by feelings of loneliness and isolation, enabling them to more fully enjoy the opportunities to receive support, immediate feedback and constructive suggestions offered by others who experience similar problems.

The results obtained in this study may amplify possibilities of comprehension and discussion of the topic of sexuality in the hospital context, providing elements to enhance the integrality of the care, not only for women who have been affected by breast cancer, but also for their companions, who are also impacted by the context of illness. In this scenario, the role of the psychologist as a healthcare professional is highlighted. Psychologists must be prepared for the range of experience possibilities found in women with breast cancer in order to improve their capabilities to diagnose the subjective needs of the women, incrementing the guidance with qualified advice.

There is a need to incorporate issues of sexuality in the interventions offered in the context of care. However, this need to contemplate the sphere of the emotional-sexual life of patients often collides with the deficient formation of the healthcare professionals, especially regarding the experience of sexuality in the disease process theme, as indicated by the findings in the literature. In this aspect, it is necessary to promote studies aimed at training professionals in order to prepare them to develop health promotion actions, including in the emotional care the issues related to the 
experience of sexuality of the women affected by breast cancer.

Another possible limitation that can be identified in this study is that the sample is composed of women who were taking part in psychosocial rehabilitation, in a program that includes integral care, with psychological care, nursing, physiotherapy and occupational therapy. It would be interesting if future studies included patients who receive only medical and hospital care, in order to verify whether there are differences in the impact of the surgery on the sexual lives of these women who have no access to rehabilitation programs. Another factor that may have contributed to limit the scope of the results is that the women who comprised the sample of this study may be part of the patient population that adapted best to surgery, while those that were more emotionally affected tended to refuse to participate in the study upon learning of its aims. Such patients may have difficulty responding or even refuse to talk about issues related to sensitive topics such as the sexual life.

\section{References}

Alicikus, Z. A., Gorken, I. B., Sen, R. C., Kentli, S., Kinay, M., Alanyali, H., et al. (2009). Psychosexual and body image aspects of quality of life in turkish breast cancer patients: A comparison of breast conserving treatment and mastectomy. Tumori, 95(2), 212-218.

Ambrósio, D. C. M., \& Santos, M. A. (2011). Vivências de familiares de mulheres com câncer de mama: uma compreensão fenomenológica. Psicologia: Teoria e Pesquisa, 27(4), 17-26.

Araújo, I. M. A., \& Fernandes, A. F. C. (2008). O significado do diagnóstico do câncer de mama para a mulher. Escola Anna Nery, 12(4), 664-671.

Avis, N. E., Crawford, S., \& Manuel, J. (2004). Psychosocial problems among younger women with breast cancer. Psycho-Oncology, 13(5), 295-308.

Barros, A. C. S. D., Barbosa, E. M., Gebrim, L. H., Anelli, A., Figueira Filho, A., Del Giglio, A., et al. (2001). Diagnóstico e tratamento do câncer de mama. In Conselho Federal de Medicina. Projeto diretrizes (pp.1-15). Brasília: CFM.

Barton-Burke, M., \& Gustason, C. J. (2007). Sexuality in women with cancer. Nursing Clinics of North America, 42(4), 531-554.

Berterö, C., \& Wilmoth M. C. (2007). Breast cancer diagnosis and its treatment affecting the self: A meta-synthesis. Cancer Nursing, 30(3), 194-202.

Biffi, R. G., \& Mamede, M. V. (2004). Suporte social na reabilitação da mulher mastectomizada: o papel do parceiro sexual. Revista da Escola de Enfermagem da USP, 38(3), 262-269.

Bloom, J. (2002). Surviving and thriving? Psycho-Oncology, 11(2), 89-92.

Brasil. Ministério da Saúde. (2011b). Resolução CNS no 196/96. Brasília: MS.

Brasil. Ministério da Saúde. (2009). Estimativas 2010: incidência de câncer no Brasil. Brasília: MS. Recuperado em outubro 23, 2010, disponível em <http://www.inca. gov.br>.

Brasil. Ministério da Saúde. (2011). Estimativas 2012: incidência de câncer no Brasil. Brasília: MS. Recuperado em março 13, 2012, disponível em <http://www.inca. gov.br>.

Brêtas, J. R. S., Ohara, C. V. S., \& Querino, I. D. (2008). Orientação sobre sexualidade para estudantes de enfermagem. Acta Paulista de Enfermagem, 21(4), 568-574.

Büchele, F., Oliveira, A. S., \& Pereira, M. D. (2006). Uma revisão sobre o idoso e sua sexualidade. Interface: Comunicação, Saúde, Educação, 3(1), 131-143.

Bukovic, D., Fajdic, J., Strinic, T., Habek, M., Hojsak, I., \& Radakovic, N. (2004). Differences in sexual functioning between patients with benign and malignant breast tumors. Collegium Antropologicum, 28(2), 191-201.

Corbellini, V. L. (2001). Câncer de mama: encontro solitário com o temor do desconhecido. Revista Gaúcha de Enfermagem, 22(1), 42-68.

Duarte, T. P., \& Andrade, A. N. (2003). Enfrentando a mastectomia: análise dos relatos de mulheres mastectomizadas sobre questões ligadas à sexualidade. Estudos de Psicologia (Natal), 8(1), 155-163.

Fatone, A. M., Moadel, A. B., Foley, F. W., Fleming, M., \& Jandorf, L. (2007). Urban voices: The quality-of-life experience among women of color with breast cancer. Palliative and Supportive Care, 5(2), 115-125.

Fontarella, B. J. B., Ricas, J., \& Turato, E. R. (2008). Amostragem por saturação nas proposições qualitativas em saúde: contribuições teóricas. Cadernos de Saúde Pública, 24(1), 17-27.

Giami, A. (2002). Sexual health: The emergence, development and diversity of a concept. Annual Review of Sex Research, 13, 1-35.

Giami, A. (2007). Permanência das representações do gênero em sexologia: as inovações científicas e médicas comprometidas pelos estereótipos de gênero. Physis, 17(2), 301-320.

Gimenes, M. G. (Org.). (1997). A mulher e o câncer. São Paulo: Editorial Psy.

Gomes, F. A., Panobianco, M. S., Ferreira, C. B., Kebbe, L. M., \& Meirelles, M. C. C. C. (2003). Utilização de grupos na reabilitação de mulheres com câncer de mama. Revista de Enfermagem UERJ, $11(3), 292-295$.

Gorisek, B., Krajnc, P., \& Krajnc, I. (2009). Quality of life and the effect on social status among Slovenian women after breast cancer treatment. Journal of International Medical Research, 37(2), 557-566. 
Kovács, M. J. (1992). Morte e desenvolvimento humano. São Paulo: Casa do Psicólogo.

Kovács, M. J. (2003). Bioética nas questões da vida e da morte. Psicologia USP, 14(2), 115-167.

Kübler Ross, E. (2005). Sobre a morte e o morrer: o que os doentes terminais têm para ensinar a médicos, enfermeiras, religiosos e a seus próprios parentes ( $5^{\mathrm{a}}$ ed.). São Paulo: Martins Fontes.

Lôbo, R. C. M. M., Santos, N. O., Dourado, G., \& Lucia, M. C. S. (2006). Crenças relacionadas ao processo de adoecimento e cura em mulheres mastectomizadas: um estudo psicanalítico. Psicologia Hospitalar, 4(1), pp.1-20.

Maluf, A. S. D., Dias, R. C., \& Barra A. A. (2006). Avaliação da qualidade de vida em mulheres com câncer de mama. Revista Brasileira de Cancerologia, 52(1), 49-58.

Muniz, R. M. (2008). Os significados da experiência da radioterapia oncológica na visão de pacientes e familiares (Tese de doutorado não-publicada). Universidade de São Paulo.

Peres, R. S., \& Santos, M. A. (2007). Breast cancer, poverty and mental health: Emotional response to the disease in women from popular classes. Revista Latino-Americana de Enfermagem, 15(Esp.), 786-791.

Peres, R. S., \& Santos, M. A. (2009). Personalidade e câncer de mama: produção científica em psico-oncologia. Psicologia: Teoria e Pesquisa, 25(4), 611-620.

Rossi, L., \& Santos, M. A. (2003). Repercussões psicológicas do adoecimento e tratamento em mulheres acometidas pelo câncer de mama. Psicologia: Ciência e Profissão, 23(4), 32-41.

Saegrov, S., \& Halding, A. G. (2004). What is it like living with the diagnosis of cancer? European Journal of Cancer Care, 13(2), 145-153.

Sales, C., Paiva, L., Scandiuzzi, D., \& Anjos, A. C. (2001). Qualidade de vida de mulheres tratadas de câncer de mama: funcionamento social. Revista Brasileira de Cancerologia, $47(3), 263-272$

Sant'Anna, D. B. (2000). A mulher e câncer na história. In M. G. G. Gimenes \& M. H. Fávero (Orgs.), A mulher e o câncer (pp.43-70). Campinas: Livro Pleno.

Santos, D. B., \& Vieira, E. M. (2011). Imagem corporal de mulheres com câncer de mama: uma revisão sistemática da literatura. Ciência e Saúde Coletiva, 16(5), 2511-2522.
Santos, M. A., \& Vieira, E. M. (2008). Aconselhamento em contracepção: grupo de capacitação de profissionais médicos do programa de saúde da família. Interface: Comunicação, Saúde, Educação, 12(26), 589-601.

Scorsolini-Comin, F., Santos, M. A., \& Souza, L. V. (2009). Vivências e discursos de mulheres mastectomizadas: negociações e desafios do câncer de mama. Estudos de Psicologia (Natal), 14(1), 41-50.

Silva, V. C. E. (2005). O impacto da revelação do diagnóstico de câncer na percepção do paciente (Dissertação de mestrado não-publicada). Programa Interinstitucional, Universidade de São Paulo.

Silva, G., \& Santos, M. A. (2008). Será que não vai acabar nunca?: perscrutando o universo do pós-tratamento do câncer de mama. Texto \& Contexto Enfermagem, 17(3), 561-568.

Silva, G., \& Santos, M. A. (2010). Stressors in breast cancer post-treatment: A qualitative approach. Revista Latino-Americana de Enfermagem, 18(4), 688-695.

Talhaferro, B., Lemos, S. S., \& Oliveira, E. (2007). Mastectomia e suas consequências na vida da mulher. Arquivos de Ciências da Saúde, 14(1), 17-22.

Tavares, J. S. C., \& Trad, L. A. B. (2005). Metáforas e significados do câncer de mama na perspectiva de cinco famílias afetadas. Cadernos de Saúde Pública, 21(2), 426-435.

Trincaus, M. R., \& Corrêa, A. K. (2006). A dualidade vida-morte na vivência dos pacientes com metástase. Revista da Escola de Enfermagem USP, 41(1), 44-51.

Triviños, A. N. S. (1987). Introdução à pesquisa em ciências sociais: a pesquisa qualitativa em educação. São Paulo: Atlas.

Vieira, C. P., Lopes, M. H. B. M., \& Shimo, A. K. K. (2007). Sentimentos e experiências na vida das mulheres com câncer de mama. Revista da Escola de Enfermagem USP, 41(2), 311-316.

World Health Organization. (1986). Basic documents. Geneva: Author.

Received on: 16/12/2011

Final version on: 23/3/2012

Approved on: 25/4/2012 
